\title{
REACTIVE INTERMEDIATES DERIVED FROM DICYCLOPENTADIENYL- NIOBIUM(III) CARBONYL COMPOUNDS
}

ECKART E.H. OTTO and HANS H. BRINTZINGER *

Fachbereich Chemie - Universität Konstanz, 7750 Konstanz (B.R.D.)

\section{Summary}

In the course of the reaction of $\left(\mathrm{C}_{5} \mathrm{H}_{5}\right)_{2} \mathrm{NbH}(\mathrm{CO})$ with Brönsted acids, the participation of two cationic intermediates has been observed. Interconversion reactions between these reactive $\left(\mathrm{C}_{5} \mathrm{H}_{5}\right)_{2} \mathrm{Nb}^{\mathrm{III}}$ derivatives and stable reaction products according to the following scheme are described.

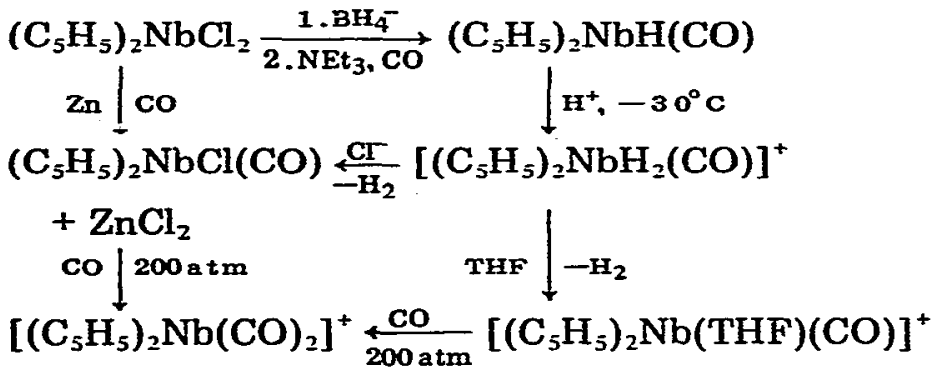

\section{Introduction}

In recent years, dicyclopentadienyl carbonyl derivatives of Group IV and Group VI transition metals have been the subject of substantial interest from the point of view of the nature of crucial intermediates and elementary reaction steps which govern their typical reactions. Several publications have also been concerned with reaction mechanisms of $\left(\mathrm{C}_{5} \mathrm{H}_{5}\right)_{2} \mathrm{~V}^{\mathrm{III}}$ carbonyl derivatives [1].

By comparison, relatively little is known about the chemistry of low-valent $\left(\mathrm{C}_{5} \mathrm{H}_{5}\right)_{2} \mathrm{Nb}^{\mathrm{III}}$ and $\left(\mathrm{C}_{5} \mathrm{H}_{5}\right)_{2} \mathrm{Ta}{ }^{\mathrm{III}}$ carbonyl derivatives. Syntheses and structures of several carbonyl compounds of the type $\left(\mathrm{C}_{5} \mathrm{H}_{5}\right)_{2} \mathrm{NbX}(\mathrm{CO})$, with $\mathrm{X}=\mathrm{H}[2-4]$, $\mathrm{SH}[5], \mathrm{C}_{2} \mathrm{HR}_{2}$ and $\mathrm{C}_{2} \mathrm{H}_{5}$ [6] have been described in the literature. More recently: Lemenowskii et al. [7] have reported that reduction of $\left(\mathrm{C}_{5} \mathrm{H}_{5}\right)_{2} \mathrm{NbCl}_{2}$ leads to the monochloro derivative $\left(\mathrm{C}_{5} \mathrm{H}_{5}\right)_{2} \mathrm{NbCl}$ which, upon exposure to $\mathrm{CO}$, yields

\footnotetext{
* To whom correspondence should be addressed
} 
$\left(\mathrm{C}_{5} \mathrm{H}_{5}\right)_{2} \mathrm{NbCl}(\mathrm{CO})$. We now report additional interconversion reactions involving some novel $\left(\mathrm{C}_{5} \mathrm{H}_{5}\right)_{2} \mathrm{Nb}^{\mathrm{III}}$ carbonyl derivatives.

\section{Results and discussion}

The most convenient starting material for syntheses of $\left(\mathrm{C}_{5} \mathrm{H}_{5}\right)_{2} \mathrm{Nb}^{\mathrm{III}}$ derivatives is the dichloro derivative $\left(\mathrm{C}_{5} \mathrm{H}_{5}\right)_{2} \mathrm{NbCl}_{2}$, which can be prepared and purified in quantity $[8,9]$. With direct reduction of this compound, as reported by Lemenowskii [7], however, we have encountered substantial complications. Strong reductants such as sodium amalgam tend to carry reduction beyond the $\left(C_{5} \mathrm{H}_{5}\right)_{2} \mathrm{Nb}^{11 I}$ stage (cf. ref. 10); if these reductions are carried out under an atmosphere of $\mathrm{CO}$ in tetrahydrofuran (THF), $\left(\mathrm{C}_{5} \mathrm{H}_{5}\right)_{2} \mathrm{NbH}(\mathrm{CO})$ is formed as the major product, apparently by hydrogen abstraction from the solvent. Milder reductants, such as zinc in THF, appear to effect specific reduction to $\left(\mathrm{C}_{5} \mathrm{H}_{5}\right)_{2} \mathrm{Nb}^{\mathrm{III}}$, but the $\mathrm{ZnCl}_{2}$ produced interferes with the isolation of pure $\left(\mathrm{C}_{5} \mathrm{H}_{5}\right)_{2} \mathrm{NbCl}$ or $\left(\mathrm{C}_{5} \mathrm{H}_{5}\right)_{2} \mathrm{NbCl}(\mathrm{CO})$. We observe, e.g., that the reddish residue of $\left(\mathrm{C}_{5} \mathrm{H}_{5}\right)_{2} \mathrm{NbCl}(\mathrm{CO})$ and $\mathrm{ZnCl}_{2}$, obtained after removal of THF from the reaction mixture is insoluble in toluene, whereas pure $\left(\mathrm{C}_{5} \mathrm{H}_{5}\right)_{2} \mathrm{NbCl}(\mathrm{CO})$ is readily soluble; this and a shift of the $C O$ absorption to $1930 \mathrm{~cm}^{-1}$ in this material, compared to $1900 \mathrm{~cm}^{-1}$ in pure $\left(\mathrm{C}_{5} \mathrm{H}_{5}\right)_{2} \mathrm{NbCl}(\mathrm{CO})$ indicate the formation of an adduct between these two reaction products *.

Reduction of $\left(\mathrm{C}_{3} \mathrm{H}_{5}\right)_{2} \mathrm{NbCl}_{2}$ with borohydride or with an equivalent amount of $\left(\mathrm{C}_{5} \mathrm{H}_{5}\right)_{2} \mathrm{NbBH}_{4}$ in THF gives a fair yield of pure toluene-soluble $\left(\mathrm{C}_{5} \mathrm{H}_{5}\right)_{2} \mathrm{NbCl}$; which can be converted to $\left(\mathrm{C}_{5} \mathrm{H}_{5}\right)_{2} \mathrm{NbCl}(\mathrm{CO})$ by excess carbon monoxide.

A clean and convenient route for a reduction of $\left(\mathrm{C}_{5} \mathrm{H}_{5}\right)_{2} \mathrm{NbCl}_{2}$ to $\left(\mathrm{C}_{5} \mathrm{H}_{5}\right)_{2} \mathrm{Nb}^{\mathrm{III}}$ carbonyl derivatives is available, however, via the carbonyl hydride derivative $\left(\mathrm{C}_{5} \mathrm{H}_{5}\right)_{2} \mathrm{NbHCO}$. We find that this compound is most conveniently synthesized by reaction of $\left(\mathrm{C}_{5} \mathrm{H}_{5}\right)_{2} \mathrm{NbBH}_{4}$ (which is available in high yields by reduction of $\left(\mathrm{C}_{5} \mathrm{H}_{5}\right)_{2} \mathrm{NbCl}_{2}$ with excess $\left.\mathrm{NaBH}=[8,9]\right)$ with triethylamine in THF under an atmosphere of $\mathrm{CO}$, and subsequent sublimation. Treatment with an excess of $\mathrm{HCl}$ in tetrahydrofuran rapidly and quantitatively converts $\left(\mathrm{C}_{5} \mathrm{H}_{5}\right)_{2} \mathrm{NbHCO}$ into $\left(\mathrm{C}_{5} \mathrm{H}_{5}\right)_{2} \mathrm{NbCl}(\mathrm{CO}) * *$.

In the reaction of $\left(\mathrm{C}_{3} \mathrm{H}_{3}\right)_{2} \mathrm{NbHCO}$ with $\mathrm{HCl}$ in THF, an initially formed intermediate can be observed if $\mathrm{HCl}$ is introduced below $0^{\circ} \mathrm{C}$, a yellow material is precipitated. This is fairly stable at temperatures up to $-30^{\circ} \mathrm{C}$, but decomposes almost instantaneously at room temperature with release of exactly $1 \mathrm{mmol} \mathrm{H}_{2}$ l mmol $\mathrm{Nb}$ to give $\left(\mathrm{C}_{5} \mathrm{H}_{5}\right)_{2} \mathrm{NbCl}(\mathrm{CO})$. This reaction, and the analogy to the known dihydridophosphine cation $\left[\left(\mathrm{C}_{5} \mathrm{H}_{5}\right)_{2} \mathrm{NbH}_{2}\left(\mathrm{PR}_{3}\right)\right]^{+}[8]$, suggest that the insoluble yellow intermediate is the chloride salt of the dihydridocarbonyl cation $\left[\left(\mathrm{C}_{5} \mathrm{H}_{5}\right)_{2} \mathrm{NbH}_{2}(\mathrm{CO})\right]^{+}$, formed by protonation of $\left(\mathrm{C}_{5} \mathrm{H}_{5}\right)_{2} \mathrm{NbH}(\mathrm{CO})$, this cation would be susceptible to reductive $\mathrm{H}_{2}$ elimination ***.

\footnotetext{
* Similar adducts have been observed in reaction systems containing $\left(\mathrm{C}_{5} \mathrm{H}_{5}\right)_{2} \mathrm{TiCl}_{5}$ and $\mathrm{ZnCl}_{2}$ [11].

** In toluene the reaction with either $\mathrm{HCl}$ or $\mathrm{CH}_{2} \mathrm{Cl}_{2}$ converts the hydridocarbonyl into the dichloro derivative $\left(\mathrm{C}_{5} \mathrm{H}_{5}\right)_{2} \mathrm{NbCl}_{2}$, together with variable amounts of other. possibly binuclear species with $\nu(C O)$ absorptions around $1850 \mathrm{~cm}^{-1}$ and parent ions in the range $\mathrm{m} / \mathrm{e} 442-479$.

* * The proposed intermediate $\left(\mathrm{C}_{5} \mathrm{H}_{5}\right)_{2} \mathrm{NbH}_{2}(\mathrm{CO})^{*}$ would be isoelectronic to the similarly unstable zirconium derivative $\left(\mathrm{C}_{5} \mathrm{Me}_{5}\right)_{2} \mathrm{Zr}_{2} \mathrm{H}_{2}(\mathrm{CO})$, recently described by Bercaw et al. [12].
} 
The immediate product formed from this reductive $\mathrm{H}_{2}$ elimination would be the 16-electron species $\left[\left(\mathrm{C}_{5} \mathrm{H}_{5}\right)_{2} \mathrm{Nb}(\mathrm{CO})\right]^{+}$. In the presence of a $\mathrm{Cl}^{-}$counteranion, this species is apparently immediately converted into $\left(\mathrm{C}_{5} \mathrm{H}_{5}\right)_{2} \mathrm{NbCl}(\mathrm{CO})$. We have tried to trap such a secondary intermediate from the protonation of $\left(\mathrm{C}_{5} \mathrm{H}_{5}\right)_{2} \mathrm{NbH}(\mathrm{CO})$ by generating it in the presence of less coordinating anions. E.g., when $\left(\mathrm{C}_{5} \mathrm{H}_{5}\right)_{2} \mathrm{NbH}(\mathrm{CO})$ is treated with a stoichiometric amount of $\mathrm{HBF}_{4}$ in THF solution, the initial yellow precipitate is converted with release of $1 \mathrm{mmol}$ $\mathrm{H}_{2} / \mathrm{mmol} \mathrm{Nb}$ into another, thermally stable, brick-red material of composition $\left[\left(\mathrm{C}_{5} \mathrm{H}_{5}\right)_{2} \mathrm{Nb}(\mathrm{CO})(\mathrm{THF})\right]^{+} \mathrm{BF}_{4}^{-}$, which is characterized by a $\nu(\mathrm{CO}) \mathrm{IR}$ absorption at $1940 \mathrm{~cm}^{-1}$. This compound is also available by direct hydride abstraction from $\left(\mathrm{C}_{5} \mathrm{H}_{5}\right)_{2} \mathrm{NbH}(\mathrm{CO})$ with $\left[\left(\mathrm{C}_{6} \mathrm{H}_{5}\right)_{3}\right]^{+} \mathrm{BF}_{4}^{-}$in THF. It seemed likely that the THF ligand in this secondary intermediate, $\left[\left(\mathrm{C}_{5} \mathrm{H}_{5}\right)_{2} \mathrm{Nb}(\mathrm{CO})(\mathrm{THF})\right]^{+}$, would be easily replaceable by other ligands, and we have observed that $\left[\left(\mathrm{C}_{5} \mathrm{H}_{5}\right)_{2} \mathrm{Nb}(\mathrm{CO})\right.$ (THF) $]^{*}$ is quantitatively converted into the novel dicarbonyl derivative $\left[\left(\mathrm{C}_{5} \mathrm{H}_{3}\right)_{2} \mathrm{Nb}(\mathrm{CO})_{2}\right]^{+} \mathrm{BF}_{3}^{-}$by treatment with $\mathrm{CO}$ at $200 \mathrm{~atm}$ and $80^{\circ} \mathrm{C}$ in toluene suspension. This dicarbonyl cation, which is readily converted to its air stable hexafluorophosphate or tetraphenylborate salts, has an IR absorption spectrum with two $\nu(\mathrm{CO})$ bands at 2060 and $2090 \mathrm{~cm}^{-1}$. These properties of $\left[\left(\mathrm{C}_{5} \mathrm{H}_{5}\right)_{2} \mathrm{Nb}\right.$ $\left.(\mathrm{CO})_{2}\right]^{+}$are in close agreement with those of its known vanadium analog [1]. It is interesting to note that much more drastic reaction conditions are required to

SCHEME 1
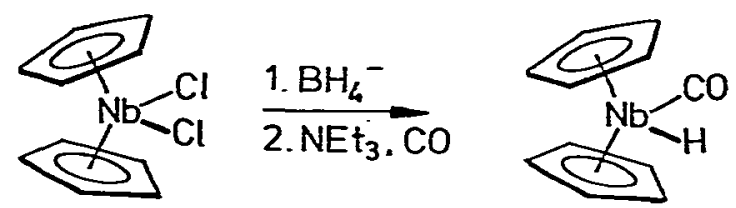

$\mathrm{Zn} \mid \mathrm{co}$

$$
\mathrm{H}^{+} .-30^{\circ} \mathrm{C}
$$
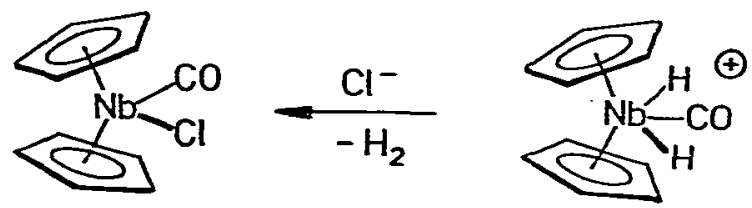

$+\mathrm{ZnCl}$

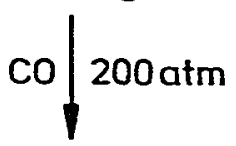<smiles></smiles>

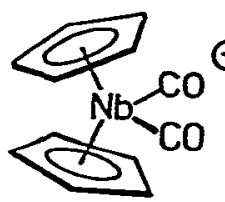

$\oplus$
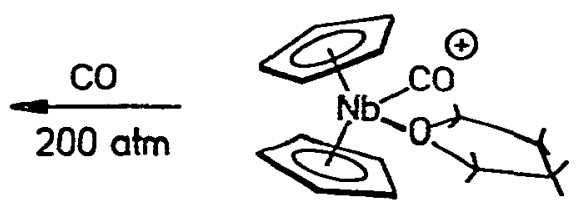
convert a $\left(\mathrm{C}_{5} \mathrm{H}_{5}\right)_{2} \mathrm{Nb}^{\mathrm{III}}$ monocarbonyl derivative into this dicarbonyl cation than is the case for the corresponding $\left(\mathrm{C}_{5} \mathrm{H}_{5}\right)_{2} \mathrm{~V}^{\mathrm{III}}$ derivatives.

Attempts to convert the chlorocarbonyl derivative to the dicarbonyl cation more directly, e.g. by reaction with $\mathrm{BF}_{3}$ or $\mathrm{BCl}_{3}$ under elevated pressures of $\mathrm{CO}$, did not lead to $\left[\left(\mathrm{C}_{5} \mathrm{H}_{5}\right)_{2} \mathrm{Nb}(\mathrm{CO})_{2}\right]^{+}$; instead, unidentified materials without any CO absorption bands were obtained. The dicarbonyl cation was obtained, however, together with some unreacted starting material, when the adduct between $\left(\mathrm{C}_{5} \mathrm{H}_{5}\right)_{2} \mathrm{NbCl}(\mathrm{CO})$ and $\mathrm{ZnCl}_{2}$, obtained from the reduction of $\left(\mathrm{C}_{5} \mathrm{H}_{5}\right)_{2} \mathrm{NbCl}_{2}$ with zinc metal under $\mathrm{CO}$ in THF was exposed to an elevated pressure of $\mathrm{CO}$ at $50-60^{\circ} \mathrm{C}$.

The interconversion reactions between the reactive $\left(\mathrm{C}_{5} \mathrm{H}_{5}\right)_{2} \mathrm{Nb}^{\mathrm{III}}$ carbonyl derivatives described above, and their stable reaction products are summarized in reaction scheme 1. Preliminary results indicate that largely analogous reactions occur with the corresponding tantalum derivatives.

\section{Experimental}

All manipulations were carried out in vacuo or under argon by Schlenk or vacuum manifold techniques. Solvents were dried with $\mathrm{LiAlH}_{4}$ and distilled in vacuo. Analysis were by the A. Bernhardt Microanalytical Laboratory, Elbach (B.R.D.).

1. $\left(\mathrm{C}_{5} \mathrm{H}_{5}\right)_{2} \mathrm{NbH}(\mathrm{CO})$ from $\left(\mathrm{C}_{5} \mathrm{H}_{5}\right)_{2} \mathrm{NbBH}_{4}$. A solution of $458 \mathrm{mg}(2 \mathrm{mmol})$ of freshly sublimed $\left(\mathrm{C}_{5} \mathrm{H}_{3}\right)_{2} \mathrm{NbBH}_{3}[8,9]$ and $0.55 \mathrm{ml}(4 \mathrm{mmol})$ of triethylamine in THF was stirred at room temperature for $4 \mathrm{~h}$ under an atmosphere of CO. Solvent and excess triethylamine were removed by distillation and the product purified by repeated sublimation. The purified product (yield $75 \%$ based on $\left.\left(\mathrm{C}_{5} \mathrm{H}_{5}\right)_{2} \mathrm{NbBH}_{4}\right)$ had a satisfactory elemental analysis, and gave spectral data identical to those reported by Tebbe and Parshall [4].

2. $\left(\mathrm{C}_{5} \mathrm{H}_{5}\right)_{2} \mathrm{NbCl}(\mathrm{CO})$ from $\left(\mathrm{C}_{5} \mathrm{H}_{5}\right)_{2} \mathrm{NbH}(\mathrm{CO})$. Into a solution of $126 \mathrm{mg}(0.5$ $\mathrm{mmol})$ of $\left(\mathrm{C}_{5} \mathrm{H}_{5}\right)_{2} \mathrm{NbH}(\mathrm{CO})$ in $40 \mathrm{ml}$ diethyl ether, cooled to $-78^{\circ} \mathrm{C}$, was condensed $1 \mathrm{ml}$ of a $1.5 \mathrm{M}$ solution of $\mathrm{HCl}$ in THF. The mixture, which contained a yellow precipitate, was stirred and allowed to warm. Above $-30^{\circ} \mathrm{C}$, the yellow solid began to dissolve to form a dark brown solution with release of $0.5 \mathrm{mmol}$ $\mathrm{H}_{2}$ - After stirring for 5-10 min at room temperature, the solvent was evaporated, and the solid residue (yield $100 \%$ based on $\left(\mathrm{C}_{5} \mathrm{H}_{3}\right)_{2} \mathrm{NbH}(\mathrm{CO})$ ) consisted of analytically pure $\left(\mathrm{C}_{5} \mathrm{H}_{5}\right)_{2} \mathrm{NbCl}(\mathrm{CO})$. Elemental analysis, Found: $\mathrm{C}, 45.96 ; \mathrm{H}, 3.61$; $\mathrm{Nb}, 32.15 ; \mathrm{Cl}, 12.45 . \mathrm{C}_{11} \mathrm{H}_{10} \mathrm{NbCl}$ calcd.: $\mathrm{C}, 46.10 ; \mathrm{H}, 3.52 ; \mathrm{Nb}, 32.42 ; \mathrm{Cl}, 12.37 \%$ IR: $\nu(\mathrm{CO})$ at $1900 \mathrm{~cm}^{-1}$ (Nujol mull; in THF solution this band appeared at $1920 \mathrm{~cm}^{-1}$ ). NMR: singlet at $\delta 4.88 \mathrm{ppm}$ in benzene-d $d_{6}$ (in acetone-d $d_{6}$ this signal is at $\delta 5.48 \mathrm{ppm})$.

3. $\left(\mathrm{C}_{5} \mathrm{H}_{5}\right)_{2} \mathrm{Nb}(\mathrm{THF})(\mathrm{CO}) \mathrm{BF}_{4}$. To a solution of $176 \mathrm{mg}(0.7 \mathrm{mmol})$ of $\left(\mathrm{C}_{5} \mathrm{H}_{5}\right)_{2} \mathrm{NbH}(\mathrm{CO})$ in $20 \mathrm{ml}$ THF at $-78^{\circ} \mathrm{C}$ was added $0.1 \mathrm{ml}$ of a $54 \%$ solution of $\mathrm{HBF}_{s}$ in diethyl ether. The initially formed yellow precipitate changed to brick-red upon warming to room temperature; at the same time, $0.7 \mathrm{mmol} \mathrm{_{2 }}$ gas was released. After stirring for $10 \mathrm{~min}$ at room temperature, the red solid was isolated by filtration, and repeatedly washed with THF and dried in vacuo at room temperature. Yield $60 \%$. Elemental analysis: Found: $C, 43.81 ; \mathrm{H}, 4.44$; $\mathrm{Nb}, 22.45 ; \mathrm{B}, 2.76 ; \mathrm{F}, 18.37 \% \mathrm{C}_{15} \mathrm{H}_{18} \mathrm{BF}_{\mathrm{S}} \mathrm{NbO}_{2}$ calcd.: $\mathrm{C}, 43.95 ; \mathrm{H}, 4.40 ; \mathrm{Nb}$, 
22.7; B, 2.68; F, 18.5\%. IR: 710w, 810s, 835s, 860s, 809s, 990s, 1050s (br). $1250 \mathrm{w}, 1280 \mathrm{w}, 1345 \mathrm{~m}, 1410 \mathrm{~m}, 1940 \mathrm{vs}, 3110$ s (in Nujol mull). NMR: singlet at $5.60 \mathrm{ppm}$, multiplets at 1.8 and $3.6 \mathrm{ppm}$ (freshly dissolved in acetonitrile $d_{3}$ ). 4. $\left(\mathrm{C}_{5} \mathrm{H}_{5}\right)_{2} \mathrm{Nb}\left(\mathrm{CO}_{2} \mathrm{BF}_{4}\right.$. A suspension of $152 \mathrm{mg}(0.45 \mathrm{mmol})$ of brick-red $\left(\mathrm{C}_{5} \mathrm{H}_{5}\right)_{2} \mathrm{Nb}$ (THF)(CO)BF, in $40 \mathrm{ml}$ toluene was stirred for $24 \mathrm{~h}$ at $80^{\circ} \mathrm{C}$ in an autoclave under 200 atm of $\mathrm{CO}$. The yellow product was isolated by filtration, dissolved in $20 \mathrm{ml}$ acetone and reprecipitated by addition of $40 \mathrm{ml}$ diethyl ether. Yield 95\%. Elemental analysis: Found: C, 39.23; H, 2.88; Nb, 25.14; B, $2.86 ; \mathrm{F}, 20.48 \%$. $\mathrm{C}_{12} \mathrm{H}_{10} \mathrm{BF}{ }_{\mathrm{s}} \mathrm{NbO}$ calcd.: C, 39.39; $\mathrm{H}, 2.75 ; \mathrm{Nb}, 25.39 ; \mathrm{B}$, 2.95; F, 20.77\%. IR: $\nu(C O)$ at 1990 and $2050 \mathrm{~cm}^{1}$ (in Nujol mull). NMR: singlet at $6.02 \mathrm{ppm}$ (in acetone- $d_{6}$ ).

\section{Acknowledgements}

We wish to thank the Deutsche Forschungsgemeinschaft and the Fonds der Chemischen Industrie for financial support of this work.

\section{References}

1 F. Galderazzo and S. Bacciarelli. Inorg. Chem., 2 (1963) 721 ; F. Calderazzo, G. Fachineiti and C. Floriani, J. Amer. Chem. Soc., 96 (1974) 36yb; G. Fachinetti and C. Floriani. J. Chem. Soc., Chem. Commun.. (1975) 578: G. Fachinetti, S. Del Nero and C. Floriani, J. Chem. Soc. A, (1976) 1046.

2 A.N. Nesmeyanov, K.N. Anisimov, N.E Kolobova and A.A. Pasynskii, quoted in ref. 3.

3 N.I. Kirilova, A.I. Gusev and Yu.T. Struchkov, Zh. Strukt. Khim., 13 (1972) 473.

4 F.N. Tebbe and G.W. Parshall, J. Amer. Chem. Soc., 93 (1971) 3793.

5 N.I. Kirilova, A.I. Gusev, A.A. Pasynskii and Yu.T. Struchkov, Zh. Strukt. Khim., 14 (1973) 868.

6 J.A. Labinger and J. Schwartz. J. Amer. Chem. Soc., 97 (1975) 1596.

7 D.A. Lemenovskii and V.P. Fedin, J. Organometal. Chem., 132 (1977) C11.

8 C.R. Lucas and M.L.H. Green. J. Chem. Soc., Chem. Commun., (1972) 1005.

9 C.R. Lucas, Inorg. Synthesis, 16 (1976) 107.

10 D.A. Lemenovskii, T.V. Baukova and V.P. Fedin, J. Organometal. Chem., 132 (1977) C14.

11 M.L.H. Green and C.R. Lucas, J. Chem. Soc. A. (1972) 1001.

12 J.M Manriquez, D.R. MeAlister, R.D. Sanner and J.E. Bercaw. J. Amer. Chem. Soc., 98 (1976) 6733. 